\title{
Inflammasome-Induced IL- $1 \beta$ Secretion in Microglia Is Characterized by Delayed Kinetics and Is Only Partially Dependent on Inflammatory Caspases
}

\author{
Saskia M. Burm, ${ }^{1}$ Ella A. Zuiderwijk-Sick, ${ }^{1}$ Anke E.J. 't Jong, ${ }^{1}$ Céline van der Putten, ${ }^{1}$ Jennifer Veth, ${ }^{1}$ Ivanela Kondova, ${ }^{2}$ \\ and $\odot$ Jeffrey J. Bajramovic ${ }^{1}$ \\ ${ }^{1}$ Alternatives Unit, ${ }^{2}$ Animal Science Department, Biomedical Primate Research Centre, 2288 GJ Rijswijk, The Netherlands
}

\begin{abstract}
Inflammasomes are multiprotein complexes that link pathogen recognition and cellular stress to the processing of the proinflammatory cytokine interleukin-1 $\beta$ (IL-1 $\beta)$. Whereas inflammasome-mediated activation is heavily studied in hematopoietic macrophages and dendritic cells, much less is known about microglia, resident tissue macrophages of the brain that originate from a distinct progenitor. To directly compare inflammasome-mediated activation in different types of macrophages, we isolated primary microglia and hematopoietic macrophages from adult, healthy rhesus macaques. We analyzed the expression profile of NOD (nucleotide-binding oligomerization domain)-like receptors, adaptor proteins, and caspases and characterized inflammasome activation and regulation in detail. We here demonstrate that primary microglia can respond to the same innate stimuli as hematopoietic macrophages. However, microglial responses are more persistent due to lack of negative regulation on pro-IL-1 $\beta$ expression. In addition, we show that while caspase 1,4 , and 5 activation is pivotal for inflammasome-induced IL- $1 \beta$ secretion by hematopoietic macrophages, microglial secretion of IL- $1 \beta$ is only partially dependent on these inflammatory caspases. These results identify key cell type-specific differences that may aid the development of strategies to modulate innate immune responses in the brain.
\end{abstract}

Key words: IL-1 $\beta$; inflammasome; inflammatory caspases; macrophages; microglia

\section{Introduction}

Microglia are the resident tissue macrophages of the CNS. Like other macrophages, they express multiple receptors of the innate immune system, including Toll-like receptors (TLRs), NOD (nucleotide-binding oligomerization domain)-like receptors (NLRs), C-type lectin receptors, and retinoic acid-inducible gene-I-like receptors (Olson and Miller, 2004; Zuiderwijk-Sick et al., 2007; Furr et al., 2008; Shah et al., 2008; Shi et al., 2012). Recent studies have implicated NLR-mediated activation of microglia in several neurodegenerative (Salminen et al., 2008; Heneka et al., 2013) and infectious brain diseases (HafnerBratkovič et al., 2012; Jamilloux et al., 2013), providing an impetus for more detailed studies of this receptor family.

NLRs can sense disturbances in cellular homeostasis caused by amongst others pathogens, large protein aggregates, and neighboring cell death. To date, 23 NLRs have been described for hu-

\footnotetext{
Received June 19, 2014; revised Oct. 31, 2014; accepted Nov. 4, 2014.

Author contributions: S.M.B. and J.J.B. designed research; S.M.B., E.A.Z.-S., A.E.J.t.J., C.v.d.P., J.V., and I.K. performed research; I.K. contributed unpublished reagents/analytic tools; S.M.B., E.A.Z.-S., A.E.J.t.J., and J.J.B. analyzed data; S.M.B. and J.J.B. wrote the paper.

This work was supported by the Dutch MS Research Foundation (MS12-805). We thank T. Haaksma for expert technical assistance. We thank Dr. E. Remarque for expert assistance with the statistical analyses and Drs. R. Bontrop, L.A. 't Hart, M.G. Netea, and J.M. van Noort for critically reading the manuscript.

The authors declare no competing financial interests.

Correspondence should be addressed to Jeffrey J. Bajramovic, PhD, Alternatives Unit, Biomedical Primate Research Centre, Lange Kleiweg 161, 2288 GJ Rijswijk, The Netherlands. E-mail: bajramovic@bprc.nl.

DOI:10.1523/JNEUROSCI.2510-14.2015

Copyright $\odot 2015$ the authors $\quad 0270-6474 / 15 / 350678-10 \$ 15.00 / 0$
}

mans (Martinon et al., 2009). Ligand recognition by NOD1 and NOD2 can directly induce transcription of proinflammatory cytokines and chemokines via $\mathrm{NF} \kappa \mathrm{B}$ and IRF3 signaling (Ting et al., 2010). Other NLRs, such as NALP1 (NACHT-, LRR-, and PYDcontaining protein 1), NALP3, NALP7, AIM2 (absent in melanoma 2), and IPAF (ICE-protease activating factor) can form multiprotein complexes called inflammasomes. These receptors can either directly or indirectly via the adaptor proteins ASC (apoptosis-associated speck-like protein containing a caspase recruitment domain) or CARDINAL (CARD inhibitor of NF- $\kappa \mathrm{B}$ activating ligands) interact with inflammatory caspases and activate them. In turn, activated caspases can process precursor proteins, such as pro-IL- $1 \beta$, to their bioactive and secreted forms. Thereby NLRs link perturbances in cellular homeostasis to the production of proinflammatory cytokines (Martinon et al., 2009; Latz, 2010; Khare et al., 2012).

Inflammasome-mediated activation of microglia is involved in both infectious (Chang et al., 2012; Kaushik et al., 2012; Lee et al., 2013) and noninfectious (Halle et al., 2008; Abulafia et al., 2009; Meissner et al., 2010) neurological diseases. Microglia express various components of the inflammasome, including NALP1, NALP3, ASC, and caspase 1 (Abulafia et al., 2009; Jamilloux et al., 2013; Shi et al., 2013). In addition, microglia can be induced to express pro-IL- $1 \beta$, which can be processed to bioactive and secreted IL- $1 \beta$ in response to pathogens, protein aggregates, and more general cellular stressors, such as ATP and reactive oxygen species (Halle et al., 2008; Abulafia et al., 2009; 
Terada et al., 2010; Hanamsagar et al., 2011; Wu et al., 2013; Walsh et al., 2014).

Although microglia resemble hematopoietic macrophages both in phenotype and function, it has recently been uncovered that they originate from a different progenitor (Ginhoux et al., 2010). Furthermore, there are indications that regulation of signaling by innate immune receptors is different in microglia (Xiao et al., 2013), and microglia have been reported to specifically employ caspases $3 / 7$ and 8 during inflammatory conditions (Burguillos et al., 2011). To directly compare inflammasomemediated activation in different types of macrophages in an outbred system with close resemblance to humans, we isolated primary microglia and hematopoietic macrophages from adult, healthy rhesus macaques. We analyzed the expression profile of NLRs, adaptor proteins, and caspases and characterized inflammasome activation and regulation in detail. Our data reveal important cell type-specific differences pertaining to the negative regulation of pro-IL- $1 \beta$ expression as well as to the inflammasomeinduced enzymatic processing of pro-IL- $1 \beta$.

\section{Materials and Methods}

Animals and cell culture. Brain, bone marrow, and blood were obtained from adult rhesus monkeys (Macaca mulatta) of either sex without neurological disease that became available from the outbred breeding colony. No animals were sacrificed for the exclusive purpose of the initiation of primary cell cultures. Better use of experimental animals contributes to the priority 3Rs program of the Biomedical Primate Research Centre. Individual identification data of the animals are listed in Table 1. Primary microglia and bone marrow-derived macrophages were isolated and cultured as described previously (Zuiderwijk-Sick et al., 2007; van der Putten et al., 2009). In short, microglia isolations were initiated from cubes of $\sim 3 \mathrm{~g}$ of prefrontal subcortical white matter tissue that were manually depleted of blood vessels and meninges. These were chopped into cubes of $<2 \mathrm{~mm}^{3}$ by using gentleMACS C tubes (Miltenyi Biotec) and incubated for $20 \mathrm{~min}$ at $37^{\circ} \mathrm{C}$ in $\mathrm{PBS}$ (Thermo Fisher Scientific) containing $0.25 \%(\mathrm{w} / \mathrm{v})$ trypsin (Thermo Fisher Scientific) and $0.2 \mathrm{mg} / \mathrm{ml}$ bovine pancreatic DNase I (Roche Diagnostics). The pellet (no centrifugation) was washed, passed over a $100 \mu \mathrm{m}$ nylon cell strainer (Corning), and spun for $7 \mathrm{~min}$ at $524 \times \mathrm{g}$. After resuspending, this was followed by Percoll (GE Healthcare Bio-Sciences) gradient centrifugation for $30 \mathrm{~min}$ $(1561 \times g$; slow brake). The pellet was washed and residual erythrocytes were depleted by hypotonic shock for $7 \mathrm{~min}$ on ice in milli-Q supplemented with $155 \mathrm{mM} \mathrm{NH}_{4} \mathrm{Cl}$ (Calbiochem), $1 \mathrm{~mm} \mathrm{KHCO}_{3}$ (Merck), and $0.2 \%(\mathrm{w} / \mathrm{v})$ bovine serum albumin (Sigma-Aldrich). After a final wash, cells were plated in tissue culture treated 6-well or 24-well plates (Corning Costar) in 1:1 v/v DMEM (high glucose)/HAM F10 Nutrient Mixture supplemented with $10 \% \mathrm{v} / \mathrm{v}$ heat-inactivated FCS, $0.5 \mathrm{~mm}$ glutamax, 50 $\mathrm{U} / \mathrm{ml}$ penicillin, and $50 \mu \mathrm{g} / \mathrm{ml}$ streptomycin (all Thermo Fisher Scientific). After overnight incubation, unattached cells and myelin debris were removed by washing with PBS and attached cells were cultured in fresh medium supplemented with $20 \mathrm{ng} / \mathrm{ml}$ macrophage colonystimulating factor (M-CSF; PeproTech).

Primary bone marrow-derived macrophages were isolated by flushing the bone marrow from the femur $(\sim 4 \mathrm{~cm})$ with PBS, followed by passing the suspension over a $100 \mu \mathrm{m}$ nylon cell strainer (Corning) and gradient centrifugation using Lymphoprep (Axis-Shield PoC) according to manufacturer's protocol. Cells were plated in tissue culture-treated 6-well or 24-well plates (Corning Costar) in RPMI (Roswell Park Memorial Institute) 1640 medium supplemented with $10 \%$ v/v heat-inactivated FCS, 2 mu glutamax, $50 \mathrm{U} / \mathrm{ml}$ penicillin, $50 \mu \mathrm{g} / \mathrm{ml}$ streptomycin (all Thermo Fisher Scientific), and $20 \mathrm{ng} / \mathrm{ml} \mathrm{M-CSF} \mathrm{(PeproTech).}$

Primary blood $\mathrm{CD}_{14}{ }^{+}$(cluster of differentiation antigen 14-positive) macrophages were isolated from heparinized blood using Lymphoprep (Axis-Shield PoC) and leucosep separation tubes. Interphases were collected and $\mathrm{CD} 14^{+}$monocytes were isolated using CD $14^{+}$microbeads (Miltenyi Biotec) and a magnetic activated cell sorting separation system. $\mathrm{CD}_{14}{ }^{+}$cells were plated in tissue culture-treated 6-well or 24-well plates
Table 1. Individual identification data of rhesus macaques

\begin{tabular}{|c|c|c|c|c|}
\hline Monkey ID number & Age (years) & Gender & Weight $(\mathrm{kg})$ & Origin \\
\hline $1 X R$ & 28 & Female & 4.3 & India \\
\hline $2 \mathrm{CL}$ & 24 & Female & 9.0 & India \\
\hline $2 C P$ & 21 & Female & 5.2 & India \\
\hline 9017 & 23 & Female & 7.7 & India \\
\hline 94045 & 6 & Female & 5.0 & Myanmar \\
\hline 94056 & 16 & Female & 9.0 & India \\
\hline 96024 & 17 & Male & 13.1 & India \\
\hline 9606117 & 9 & Male & 12.8 & China \\
\hline R00049 & 11 & Male & 9.6 & India \\
\hline R00063 & 11 & Male & 8.4 & Myanmar \\
\hline R011141 & 11 & Male & 10.1 & Unknown \\
\hline R02032 & 10 & Male & 8.9 & Myanmar \\
\hline R02052 & 11 & Female & 7.3 & India \\
\hline R02093 & 11 & Female & 9.8 & Mix \\
\hline R03042 & 9 & Female & 5.1 & Myanmar \\
\hline R04027 & 9 & Female & 4.3 & Myanmar \\
\hline R04053 & 10 & Female & 6.6 & Mix \\
\hline R04055 & 7 & Male & 9.2 & Mix \\
\hline R04058 & 7 & Male & 8.6 & Mix \\
\hline R04067 & 9 & Female & 10.6 & Mix \\
\hline R04080 & 6 & Female & 5.0 & India \\
\hline R04108 & 9 & Female & 8.1 & Mix \\
\hline R05074 & 9 & Female & 5.2 & Myanmar \\
\hline R05098 & 6 & Male & 13.3 & Mix \\
\hline R06026 & 8 & Male & 11.8 & India \\
\hline R06043 & 8 & Male & 11.0 & India \\
\hline R06084 & 4 & Male & 4.5 & Myanmar \\
\hline R06106 & 6 & Male & 10.4 & Mix \\
\hline R07097 & 6 & Male & 5.2 & Myanmar \\
\hline R07108 & 7 & Male & 6.7 & India \\
\hline R08045 & 4 & Female & 3.6 & Myanmar \\
\hline R11088 & 2 & Female & 2.7 & India \\
\hline R99007 & 14 & Female & 5.7 & Mix \\
\hline Ri0511002 & 5 & Female & 3.7 & China \\
\hline Ri201108 & 9 & Female & 5.4 & China \\
\hline Ri202062 & 4 & Female & 5.8 & China \\
\hline Ri202224 & 10 & Female & 6.0 & China \\
\hline Ri204252 & 10 & Female & 5.1 & China \\
\hline Ri303103 & 9 & Male & 8.9 & China \\
\hline Ri306029 & 6 & Male & 10.7 & China \\
\hline
\end{tabular}

(Corning Costar) in RPMI 1640 medium supplemented with 10\% v/v heat-inactivated FCS, $2 \mathrm{~mm}$ glutamax, $50 \mathrm{U} / \mathrm{ml}$ penicillin, $50 \mu \mathrm{g} / \mathrm{ml}$ streptomycin (all Thermo Fisher Scientific), and $20 \mathrm{ng} / \mathrm{ml} \mathrm{M-CSF}$ (PeproTech).

After isolation, cell populations were kept in culture for 7 or $8 \mathrm{~d}$ (without passaging) and received 1:1 fresh medium every 3-4 d supplemented with $20 \mathrm{ng} / \mathrm{ml}$ M-CSF (PeproTech). Cell cultures were synchronized for medium changes as well as for exposure to experimental stimuli. Different cell populations were analyzed (data not shown) for purity (there were no significant differences in percentage CD11b + cells), morphological criteria indicative of activation (absent), and proliferation rate by Ki-67 immunostainings (there were no significant differences in percentage proliferating cells at time of stimulation). All cell culture media were analyzed for possible LPS contamination using a TLR4 bioassay: none of the media contained $>10 \mathrm{fg}$ of LPS/ml (data not shown).

Antibodies and reagents. Monoclonal antibodies against human caspase 1 (IMG5028, Novus Biologicals) and polyclonal antibodies against human caspase 4 and 5 (4450S and 4429S, Cell Signaling Technology) and human IL-1 $\beta$ (H-153, Santa Cruz Biotechnology) were used. Secondary mouse anti-rabbit-IgG-HRP and goat anti-mouse-IgGHRP were obtained from Jackson ImmunoResearch Laboratories.

TLR ligands used were TLR1/2 agonist $\mathrm{Pam}_{3} \mathrm{CSK}_{4}(500 \mathrm{ng} / \mathrm{ml})$, TLR3 agonist polyiosinic-polycytidylic acid $(20 \mu \mathrm{g} / \mathrm{ml})$, TLR8 agonist CL075 $(1 \mu \mathrm{g} / \mathrm{ml}$; all Invivogen) and TLR4 agonist LPS (100 ng/ml, unless indi- 
cated otherwise; from Escherichia coli serotype O26:B6; Sigma-Aldrich). Inflammasome-activating agents used were monosodium urate (MSU) crystals (150 $\mu \mathrm{g} / \mathrm{ml}$; Invivogen), ATP (5 mM), and silica (500 $\mu \mathrm{g} / \mathrm{ml}$; Sigma-Aldrich).

Fluorochrome inhibitor of caspase assays (FLICA; AbD Serotec) to determine specific caspase 1 activity were performed according to manufacturer's instructions. Caspase inhibitors specific for caspase 1 (ZYVAD-FMK; 10-40 $\mu \mathrm{M}$ ), caspase 4 (Z-LEVD-FMK; 10-40 $\mu \mathrm{M}$ ), and caspase 5 (Z-WEHD-FMK; $10-40 \mu \mathrm{M}$ ) were from BioVision. Concentrations of inflammasome-activating agents and caspase inhibitors were based on earlier studies (Zuiderwijk-Sick et al., 2007; Halle et al., 2008; Zhou et al., 2011).

RNA isolation, cDNA synthesis, and real-time PCRs. Total cellular RNA was isolated using TriReagent (Sigma-Aldrich) or the RNeasy minikit (Qiagen) according to manufacturer's protocol. Subsequently, $1 \mu \mathrm{g}$ of template mRNA was reverse transcribed into cDNA with the RevertAid First Strand cDNA synthesis kit (Thermo Fisher Scientific) according to manufacturer's protocol. Probes for real-time PCRs were designed using the Universal Probe Library design center (Roche Applied Science). Realtime quantitative PCRs were performed on the CFX96 real-time PCR detection system (Bio-rad Laboratories) using primer (Thermo Fisher Scientific) and probe (Exiqon ProbeLibrary, Roche) combinations listed in Table 2, and iTaq Universal Probes Supermix (Biorad). Relative gene expression was standardized to $\beta$-actin using the Pfaffl method (Pfaffl, 2001).

Cytokine analysis. Sandwich ELISA kits for human IL-1 $\beta$ (R\&D Systems) were used for quantification of IL- $1 \beta$ in cell culture supernatants according to manufacturer's instructions.

Western blot analysis. Culture supernatants were collected and residual crystals or cellular debris was removed by short centrifugation at 12,000 $\times g$. To remove large proteins, $1: 1 \mathrm{v} / \mathrm{v}$ acentonitrile (ICN Biomedicals) was added, followed by $30 \mathrm{~min}$ incubation at room temperature and short centrifugation at $12,000 \times g$. Thereafter, supernatants were concentrated using $10 \mathrm{kDa}$ microcentrifuge tubes (Merck). Concentrates were collected and standardized to volume.

Cell lysates were prepared in mammalian protein extraction reagent supplemented with Halt protease and phosphatase inhibitor mixture (Thermo Fisher Scientific) according to manufacturer's instructions. Cell lysates were standardized to protein concentrations that were determined using Bradford assays (Thermo Fisher Scientific).

Culture supernatants and cell lysates were separated on $12 \%$ Bis/Tris gel in NuPage MOPS [3-( $N$-morpholino)propanesulfonic acid] buffer (Thermo Fisher Scientific). Proteins were transferred to nitrocellulose membranes (GE Healthcare Bio-Sciences) by semidry blotting. Membranes were probed with indicated primary and secondary antibodies, and developed with chemiluminescence (Thermo Fisher Scientific).

Statistics. All data are depicted as means \pm SD. Graphpad Prism 6 (Graphpad Software, 2014, version 6.0e) for Macintosh was used for graphical representations. Statistical analyses were performed using Microsoft Excel for Mac (Microsoft, 2011, version 14.4.1) and the R statistical package (R Development Core Team, 2009, version 3.02).

\section{Results}

We first assessed mRNA expression levels of different inflammasome components in primary microglia, bone marrowderived macrophages (BMDMs), and blood $\mathrm{CD} 14^{+}$-derived macrophages (CD14Ms; Fig. 1A). mRNA transcripts for NLR family members NALP1-NALP3, AIM2, IPAF, NAIP (neuronal aptosis inhibitory protein), MALT (mucosa-associated lymphoid tissue lymphoma-translocation gene), and NOD1-NOD4 were detectable in all cell types, while transcripts for NALP4-NALP14 were below detection levels. In addition, all cell types expressed transcripts for the adaptor proteins ASC, CARDINAL, EBP1 (end binding protein 1), and PKR (double-stranded RNA-activated protein kinase) as well as transcripts for caspase 1, 3-5, 7, and 8 . Expression levels of adaptor protein- and caspase-encoding tran-
Table 2. Overview of primer/probe combinations used for real-time quantitative PCR

\begin{tabular}{|c|c|c|c|c|}
\hline $\begin{array}{l}\text { Gene } \\
\text { name }\end{array}$ & $\begin{array}{l}\text { Universal } \\
\text { probe } \\
\text { number }\end{array}$ & $\begin{array}{l}\text { Forward primer } \\
\left(5^{\prime} \rightarrow 3^{\prime}\right)\end{array}$ & $\begin{array}{l}\text { Reverse primer } \\
\left(5^{\prime} \rightarrow 3^{\prime}\right)\end{array}$ & $\begin{array}{l}\text { Amplicon } \\
\text { length (nt) }\end{array}$ \\
\hline AIM2 & 3 & agcctgagcagaaacagagg & ccataactggcaaacagtctttc & 78 \\
\hline ASC & 65 & gaactggacctgcaaggact & tcctccaccaggtaggactg & 66 \\
\hline$\beta$-Actin & 63 & gcccagcacgatgaagat & cgccgatccacacagagta & 65 \\
\hline CARDINAL & 81 & tgacgattgggtttggttc & agccactgttcatggtgct & 67 \\
\hline CASP1 & 4 & $\begin{array}{l}\text { ccaggacattaaaataaggaa } \\
\text { attgt }\end{array}$ & ccaaaaacctttacagaaggatctc & 77 \\
\hline CASP3 & 68 & tggaattgatgcgtaatgtt & tggctcagaagcacacaаac & 73 \\
\hline CASP4 & 26 & ttccgggcaattgaaaatgg & tgcaagctgtactaatgaaggtg & 85 \\
\hline CASP5 & 80 & ttgctttctgttcttcaacacc & tgaagatggagccetttg & 66 \\
\hline CASP7 & 25 & gctgacttcctcttcgecta & caaaccaggagcctcttcct & 76 \\
\hline CASP8 & 55 & catggaccacagtaacaagga & gccatagatgatgecettgt & 73 \\
\hline CD14 & 74 & gcatcctgcttgttgctg & tcgtccagctcacaaggtt & 77 \\
\hline EBP1 & 62 & gacgaggcagctgagttga & ttccgaagtagaaatccctctct & 88 \\
\hline IL-1 $\alpha$ & 6 & aataacctggaggccatcg & gctaaaaggtgecgacctg & 69 \\
\hline IL-1R $\alpha$ & 16 & tgcctgtcctgtgtcaagtc & cgcttgtcctgttttctgttc & 95 \\
\hline IL-6 & 40 & acaaaagtcctgatccagttcc & gtcatgtectgcagccact & 131 \\
\hline IL-8 & 4 & tctgtgtaaacatgacttccaagc & cactccttggcaaaactgc & 96 \\
\hline IPAF & 18 & aagtgaaccctgtgaccttga & accaaattgtgaagattctgagc & 96 \\
\hline MALT & 4 & ccagactcagttcactgcaaaa & gcaatgagaggtttcccaac & 130 \\
\hline MYD88 & 80 & gcaaggaatgtgacttccaga & gatggggatcagtcgcttc & 77 \\
\hline NAIP & 6 & gacagcgtggtggaaattg & gttgtccagtgctcgaaagaaa & 129 \\
\hline NALP1 & 45 & catcctgcctgccaactca & cctcagctcctgectcatct & 75 \\
\hline NALP2 & 11 & caccctccagacactccg & cagtatcaataatcagttgtgggttg & 104 \\
\hline NALP3 & 74 & cacctgttgtgcaatctgaag & gcaagatcctgacaacacgc & 74 \\
\hline NALP4 & 87 & cggtcctggtatacctgatgct & tcagagatgtattcacagcac & 67 \\
\hline NALP5 & 14 & gectctcagtgatgccttg & tgatgccacagtcctcca & 71 \\
\hline NALP6 & 75 & tctcgaggcaccacaaaaca & gactttgcagtgggacagc & 111 \\
\hline NALP7 & 30 & gctggactggacagactgc & tccttgcagctgaggtagaac & 66 \\
\hline NALP8 & 1 & ccctgaagaaccctgactgt & agcagatagaggtgaacagg & 69 \\
\hline NALP9 & 7 & ctggacgaaggctcaggaag & cagggacgggaagacaggtt & 110 \\
\hline NALP10 & 40 & gaggggtttgagtcccaag & cgtggggagtgtatgtctcc & 64 \\
\hline NALP11 & 1 & ccttaatgatatttcggaaaggattc & gcagtcgagatataggacaactt & 93 \\
\hline NALP12 & 83 & gcctaggggaatgtgtcaac & gggtttgagtgctccttcac & 70 \\
\hline NALP13 & 80 & tcagcttgtaacctcaagtatc & caaggccaggtcctgacagc & 75 \\
\hline NALP14 & 82 & ttgagatatccaaactgtaacattca & catttttatcagtctttggttgcag & 117 \\
\hline NOD1 & 24 & acaacaatctcaacgactacgg & cagtgatctggtttacgctgag & 90 \\
\hline NOD2 & 74 & gactacaactctgtgggtgacatt & tgagatattgttatcgcgcaaat & 93 \\
\hline NOD3 & 34 & aggtcggcaaggacttctc & acacagcttctcgtgggtgt & 71 \\
\hline NOD4 & 38 & catcagagctgtgggtcctc & caggtacttcttggccaactcta & 75 \\
\hline PKR & 13 & aaaacacagaattgacggaaaga & tcaagttttgccaatgctttt & 96 \\
\hline Pro-IL-1 $\beta$ & 10 & aaagcttggtgatgtctggtc & ggacatggagaacaccacttg & 89 \\
\hline Pro-IL-18 & 87 & gccaactctggctgctaaa & cagcagccatctttattcctg & 135 \\
\hline $\operatorname{TGF} \beta$ & 31 & actactacgccaaggaggtcac & tgcttgaacttgtcatagatttcg & 73 \\
\hline TLR2 & 1 & cggectgtggtacatgaaa & atgtccctgttgggagctt & 78 \\
\hline TLR4 & 69 & aatcccctgaggcatttagg & tcaattgtctggatttcacacc & 92 \\
\hline $\operatorname{TNF} \alpha$ & 79 & aagectgtageccatgttgt & gctggttatctgtcagctcca & 112 \\
\hline
\end{tabular}

Overview of primer/probe combinations used for real-time quantitative $P C R$, including sequences $\left(5^{\prime} \rightarrow 3^{\prime}\right)$ of forward and reverse primer, human Universal Probe Library number of corresponding probe, and amplicon length (in nucleotides (nt)). AIM2, Absent in melanoma 2; ASC, apoptosis-associated speck-like protein containing a caspase recruitment domain; CARDINAL (CARD8), CARD inhibitor of NF- $\kappa B$-activating ligands; CASP, caspase; CD14, cluster of differentiation antigen 14; EBP, end binding protein; IPAF, ICE-protease activating factor; MALT, mucosaassociated lymphoid tissue lymphoma-translocation gene; MyD88, myeloid differentiation primary response 88; NAIP, neuronal apoptosis inhibitor protein; NALP, NACHT-, LRR-, and PYD-containing protein; NOD, nucleotidebinding oligomerization domain; PKR, double stranded RNA-activated protein kinase; TGF, transforming growth factor; TLR, Toll-like receptor; TNF, tumor-necrosis factor.

scripts were relatively abundant when compared with levels of NLR-encoding transcripts.

The expression profiles are consistent with the notion that all these cell types can form functional inflammasomes. Yet, comparison of relative mRNA expression levels of microglia, BMDMs, and CD14Ms (Fig. 1B) revealed interesting differences. Where mRNA expression levels in BMDMs and CD14Ms were 

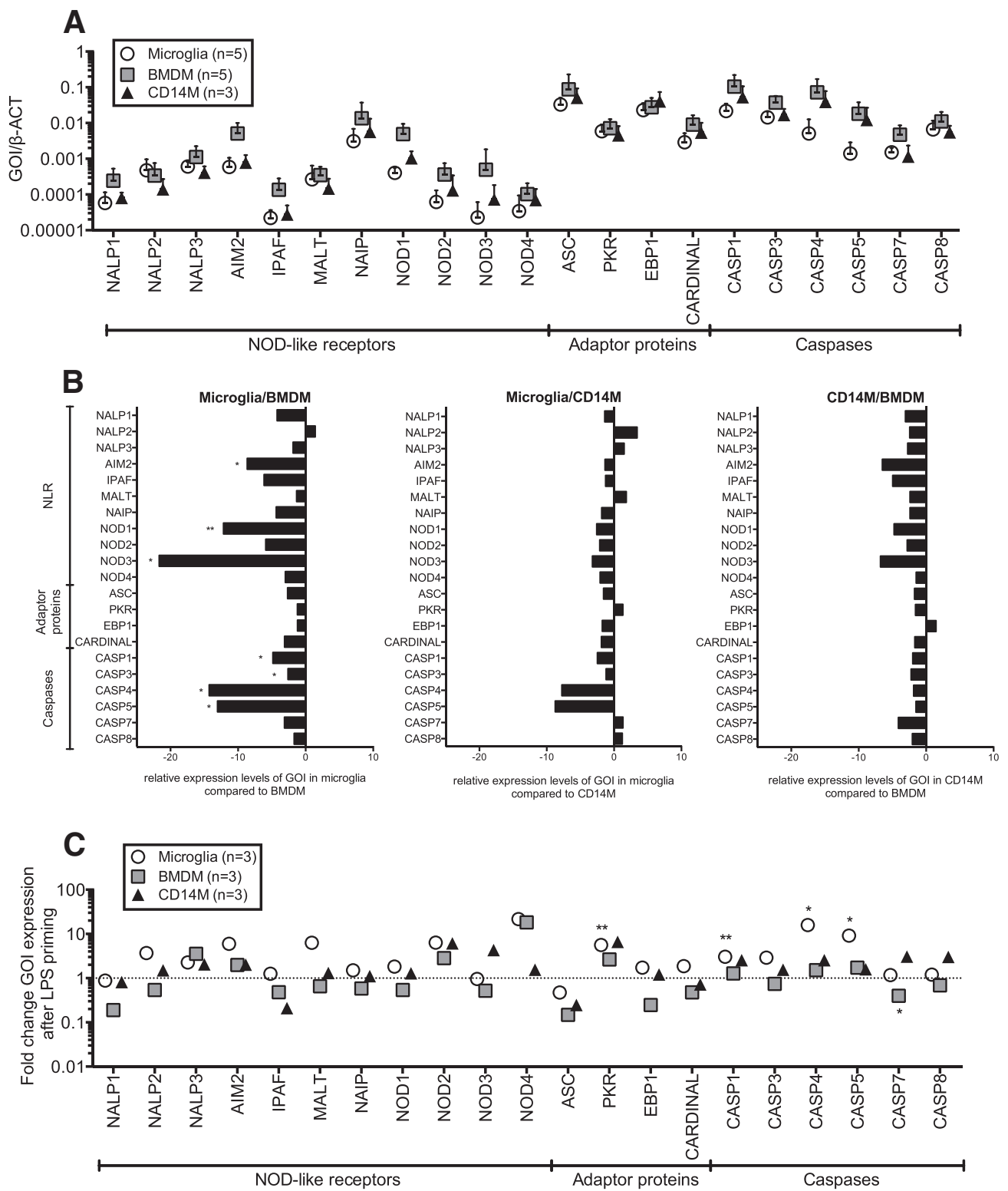

D
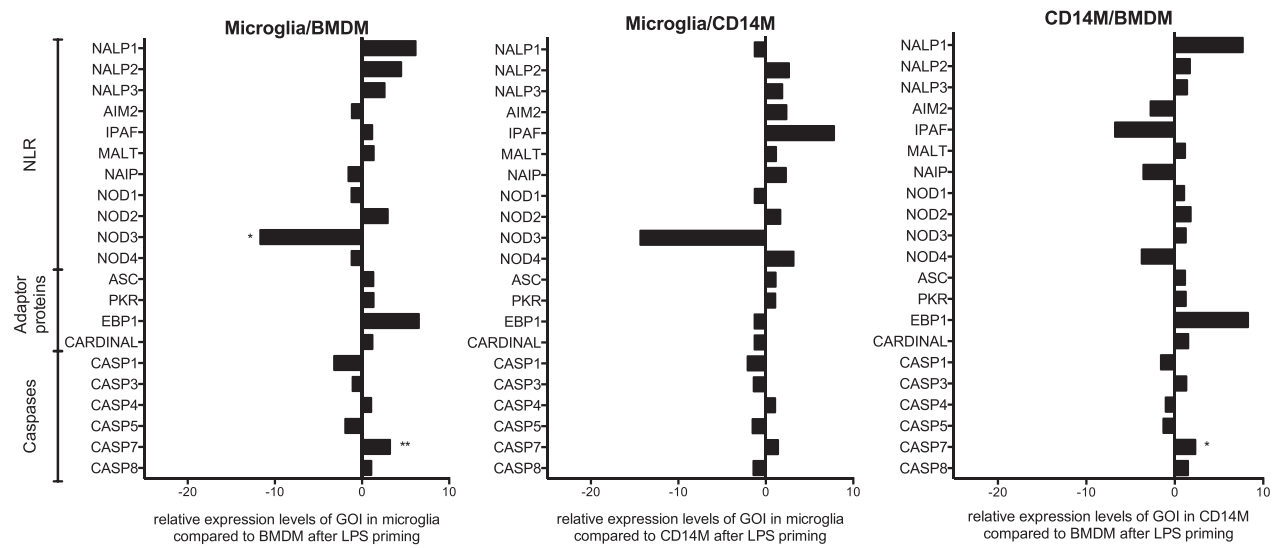

Figure 1. mRNA expression profile of inflammasome components in primary rhesus microglia, BMDMs, and CD14Ms. A, mRNA expression levels of NLRs, adaptor proteins, and caspases in primary rhesus microglia, BMDMs, and CD14Ms. mRNA expression levels of genes of interest (GOI) are expressed relative to reference gene $[\beta$-actin ( $\beta$-ACT)] mRNA expression levels. Data are represented as means \pm SD. NALP4-NALP11, NALP13, and NALP14 mRNA expression levels were below detection limits and low expression levels of NALP12 prohibited reliable quantification of all samples. $\boldsymbol{B}$, Relative mRNA expression levels compared between microglia and BMDMs, between microglia and CD14Ms, and between CD14Ms and BMDMs. C, Fold increases in relative mRNA expression levels of NLRs, adaptor proteins, and caspases after $16 \mathrm{~h}$ exposure to $\mathrm{LPS}(100 \mathrm{ng} / \mathrm{ml})$ in microglia, BMDMs, and CD14Ms. Data are represented as mean values. D, Relative mRNA expression levels after $16 \mathrm{~h}$ exposure to LPS (100 ng/ml) compared between microglia and BMDMs, between microglia and CD14Ms, and between CD14Ms and BMDMs. ${ }^{*} p<0.05,{ }^{* *} p<0.01$; ANOVA with Tukey's HSD correction. 
comparable, microglia expressed significantly lower levels of AIM2, NOD1, NOD3, caspase 1, 3, 4, and 5-encoding mRNA transcripts compared to BMDMs. In addition, levels of caspase 4 and 5-encoding mRNA transcripts were lower in microglia when compared with CD14Ms, although this was not significant.

As in vitro inflammasome activation is most often monitored in cells that have been primed with a TLR agonist (Martinon et al., 2002; Netea et al., 2009; Zhou et al., 2011), we also analyzed mRNA expression levels after overnight exposure to the TLR4 agonist LPS. Comparison to nonstimulated cells revealed LPSinduced changes in mRNA expression levels of many inflammasome components in all cell types (Fig. 1C). Priming of microglia significantly enhanced expression levels of PKR and caspase 1, 4, and 5 transcripts. Comparison of relative expression levels between cell types after LPS priming revealed that the mRNA expression profile of microglia now more closely resembled that of hematopoietic macrophages (Fig. 1D). The expression levels of transcripts encoding caspase 1, 3, 4, and 5 were now similar in all macrophages, but LPS-primed microglia still expressed markedly lower levels of NOD3-encoding transcripts compared with BMDMs and CD14Ms.

For functional analysis of inflammasome-mediated activation in microglia and BMDMs, cells were primed with different TLR agonists before triggering the inflammasome with silica, MSU crystals, or ATP (Martinon et al., 2006; Zhou et al., 2011). Priming of microglia and BMDMs by exposure to TLR1/2, TLR4, or TLR 8 agonists strongly induced pro-IL- $1 \beta$-encoding mRNA expression levels, whereas exposure to a TLR3 agonist was much less effective (Fig. 2A). Consistent with literature (Halle et al., 2008; Netea et al., 2009), secretion of IL- $1 \beta$ protein in response to TLR priming alone was $<500 \mathrm{pg} / \mathrm{ml}$ or below detection levels both in microglia as well as in BMDMs (Fig. 2B). Exposure of microglia and BMDMs that were primed with the TLR4 agonist LPS to inflammasome activators strongly induced processing and secretion of IL-1 $\beta$ (Fig. $2 C, D$ ). Whereas the physiological relevance of MSU and ATP for microglia is clear (Shi et al., 2003; Rock and Kono, 2008; Euser et al., 2009; Hanamsagar et al., 2011; Maetzler et al., 2011; McFarland et al., 2013; Martins et al., 2014), it is less likely that they will encounter silica. However, as silica and MSU were more potent in triggering inflammasomemediated activation in microglia than ATP, we chose to continue our studies with these stimuli.

We first characterized the influence of priming on inflammasome-mediated activation by varying the length of the priming period before inflammasome activation. In microglia, silica-induced IL- $1 \beta$ secretion was detectable from $2 \mathrm{~h}$ after LPS priming onwards and increased gradually for $\leq 12 \mathrm{~h}$ after LPS priming (Fig. $3 A$ ). Priming for $>16 \mathrm{~h}$ led to lower levels of secreted IL- $1 \beta$. In BMDMs, silica-induced IL- $1 \beta$ secretion was detected as early as $1 \mathrm{~h}$ after LPS priming. Much higher levels of secreted IL- $1 \beta$ were obtained if BMDMs were primed with LPS for $6-8 \mathrm{~h}$, whereas priming for $>8 \mathrm{~h}$ led to lower levels of secreted IL-1 $\beta$ (Fig. 3A). Similar differences in kinetics were found between microglia and CD14Ms and also applied to MSUinduced inflammasome activation. Analysis of the ratio of inflammasome-induced secretion of IL- $1 \beta$ after $16 \mathrm{~h}$ of LPS priming to inflammasome-induced secretion of IL- $1 \beta$ after $4 \mathrm{~h}$ of LPS priming confirmed that these kinetics differ significantly between microglia and hematopoietic macrophages (Fig. $3 B$ ).

We examined whether the different kinetics of IL- $1 \beta$ secretion in microglia could be attributed to differences in sensitivity to LPS-induced signaling. However, basal expression levels of TLR2-, TLR4-, CD14-, and MyD88 (myeloid differentiation pri- mary response 88)-encoding transcripts were similar for microglia and other macrophages (Fig. $4 A$ ). In addition, priming of microglia and BMDMs with different concentrations of LPS resulted in similar differences in IL- $1 \beta$ secretion profiles between microglia and BMDMs (Fig. 4B). Finally, we assessed pro-IL- $1 \beta$ encoding mRNA levels in more detail after LPS priming (Fig. 4C). Pro-IL-1 $\beta$ mRNA transcripts were strongly induced already after $1 \mathrm{~h}$ of LPS priming in both microglia and BMDMs. However, while pro-IL-1 $\beta$ mRNA transcript levels were downregulated already $4 \mathrm{~h}$ after LPS priming in BMDMs, they remained high in microglia. Analysis of other cytokine-encoding mRNA transcripts after priming with LPS demonstrates that the lack of negative regulation on pro-IL- $1 \beta$ transcripts also applied to IL- $1 \alpha$ and IL-8 (Fig. 4C). Other LPS-inducible transcripts like those of IL-1R $\alpha$ (IL-1 receptor antagonist), IL-6, and TNF- $\alpha$ (tumornecrosis factor $\alpha$ ) were subject to regulation in both microglia as well as in BMDMs.

To examine the processing and secretion of IL- $1 \beta$ in more detail, we first monitored the activation of caspase 1 , the principal inflammasome-activated caspase described (Martinon and Tschopp, 2004). To our surprise, silica-induced caspase 1 activation could not be detected in microglia that were primed with LPS for $4 \mathrm{~h}$. Only after $16 \mathrm{~h}$ of LPS priming some caspase 1 activation could be observed (Fig. 5A). This was in marked contrast to BMDMs, where robust silica-induced caspase 1 activation was detectable $4 \mathrm{~h}$ after LPS priming, while longer priming resulted in decreased caspase 1 activation. Western blot analysis of caspase 1 expression revealed that although both microglia and BMDMs expressed caspase 1, BMDMs expressed an additional isoform at $30 \mathrm{kDa}$ and an additional high molecular-weight band at $55 \mathrm{kDa}$, indicative of a protein complex (Fig. $5 B$ ). In addition, Western blot analysis revealed that both microglia and BMDM expressed approximately similar amounts of the inflammatory caspases 4 and 5 under basal conditions and after LPS priming. Similar to caspase 1, BMDMs expressed an additional isoform of caspase 4 at $40 \mathrm{kDa}$. To assess their functional involvement in the secretion of IL- $1 \beta$, we specifically inhibited caspase 1,4 , and 5 before activating the inflammasome (Fig. 5C). In LPS-primed microglia and BMDMs, inhibition of caspase 1 inhibited silicainduced IL- $1 \beta$ secretion by $\leq 46$ and $59 \%$ respectively. Inhibition of caspase 4 and 5 inhibited silica-induced IL- $1 \beta$ secretion in microglia by $\leq 41$ and $53 \%$ respectively, compared with $\leq 84$ and $86 \%$ inhibition in BMDMs respectively. Whereas inhibition of caspase 4 and 5 in BMDMs was clearly dose dependent, this was not the case for microglia, suggesting that exposure to even higher concentrations of caspase inhibitors would not lead to a further reduction in silica-induced IL- $1 \beta$ secretion in microglia. This could not be directly tested, as the necessary dissolvent controls affected cellular homeostasis (data not shown). However, simultaneous inhibition of caspase 1,4 , and 5 inhibited silica-induced IL- $1 \beta$ secretion in microglia by $\leq 38 \%$, whereas this inhibited silica-induced IL- $1 \beta$ secretion in BMDMs by $\leq 84 \%$. Together these data indicate that microglia are less dependent on inflammatory caspases than BMDMs for the secretion of silica-induced IL- $1 \beta$.

\section{Discussion}

Although microglia have long been considered similar to other myeloid macrophages, it is becoming more and more apparent that they differ in many respects, as illustrated by the distinct roles that resident microglia and peripheral macrophages play in CNS injury (Raivich and Banati, 2004; Greenhalgh and David, 2014). Differences in regulation of innate immune responses (Xiao et al., 2013) and alternative use of caspases have been described for 

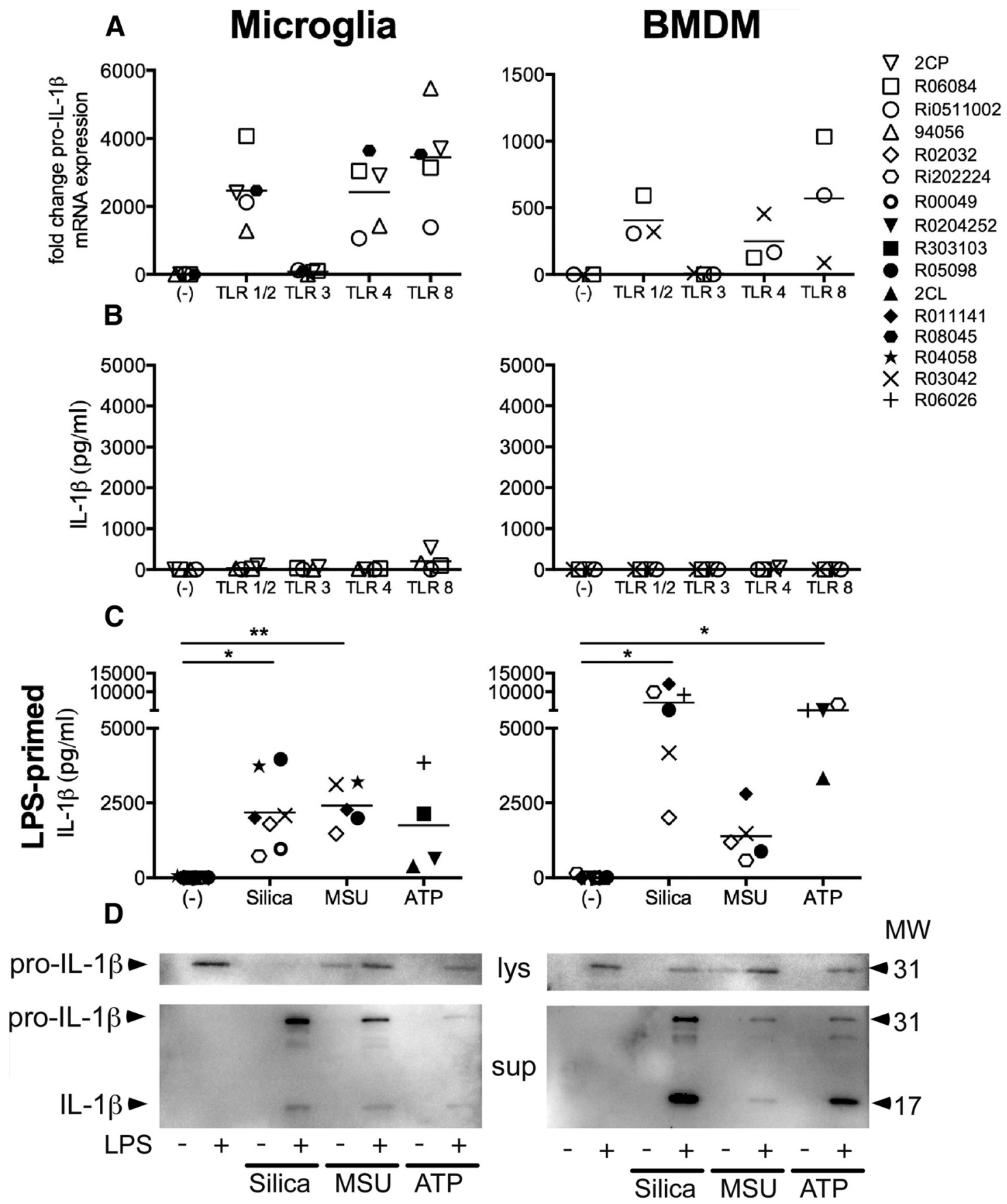

Figure 2. TLR-mediated priming of microglia and BMDMs induces the expression of pro-IL-1 $\beta$-encoding mRNA, but processing and secretion of IL-1 $\beta$ is measured only after inflammasome activation. $A$, Relative pro-IL-1 $\beta$-encoding mRNA expression levels in primary rhesus microglia and BMDMs. Cells were exposed for $16 \mathrm{~h}$ to TLR1/2 (PAM CSK $_{4}, 500 \mathrm{ng} / \mathrm{ml}^{2}$ ), TLR3 (polyiosinicpolycytidylic acid, $20 \mu \mathrm{g} / \mathrm{ml}$ ), TLR4 (LPS, $100 \mathrm{ng} / \mathrm{ml})$, and TLR8 (CL075, $1 \mu \mathrm{g} / \mathrm{ml}$ ) agonists. $B$, Levels of secreted IL- $\beta$ by TLR-primed microglia and BMDMs. C, Levels of secreted IL-1 $\beta$ by LPS-primed ( $100 \mathrm{ng} / \mathrm{ml}, 4 \mathrm{~h})$ microglia and BMDMs exposed to inflammasome inducers silica $(500 \mu \mathrm{g} / \mathrm{ml}, 6 \mathrm{~h}), \mathrm{MSU}(150 \mu \mathrm{g} / \mathrm{ml}, 6 \mathrm{~h})$, or ATP $(5 \mathrm{~mm}, 6 \mathrm{~h}) .{ }^{*} p<0.05$, ${ }^{* *} p<0.01 ;$ paired $t$ tests with Bonferroni's correction compared with unstimulated cells (-). D, Western blot analysis of pro-IL-1 $\beta$ and cleaved IL-1 $\beta$ protein in cell lysates (lys) and supernatant (sup) of LPS-primed (100 ng/ml, $4 \mathrm{~h}$ ) microglia and BMDMs that were exposed to silica $(500 \mu \mathrm{g} / \mathrm{ml}, 6 \mathrm{~h})$, MSU $(150 \mu \mathrm{g} / \mathrm{ml}, 6 \mathrm{~h})$, or ATP ( $5 \mathrm{~mm}, 6 \mathrm{~h})$. Arrows indicate molecular weight (MW) in kilodaltons.

microglia in earlier studies (Burguillos et al., 2011). Our data now identify new and important cell type-specific differences in inflammasome-mediated responses.

Results from this study demonstrate that microglia and hematopoietic macrophages are in principle endowed with similar inflammasome machinery. Published or online datasets on gene expression profiles of rodent microglia and macrophages (Chiu et al., 2013; Hickman et al., 2013; Butovsky et al., 2014) did not reveal differences in expression levels of inflam- masome components between microglia and hematopoietic macrophages and are thus in line with most of our results. However, we report here that there are relatively large differences for two transcripts in particular. Resting microglia express less caspase 4 and 5 than resting BMDMs and CD14Ms (Fig. 1A). As caspase 4 and 5 are not encoded for in rodents, which express the orthologue caspase 11 (Martinon and Tschopp, 2004), this is a new finding that underlines the added value of studies using primate material. 

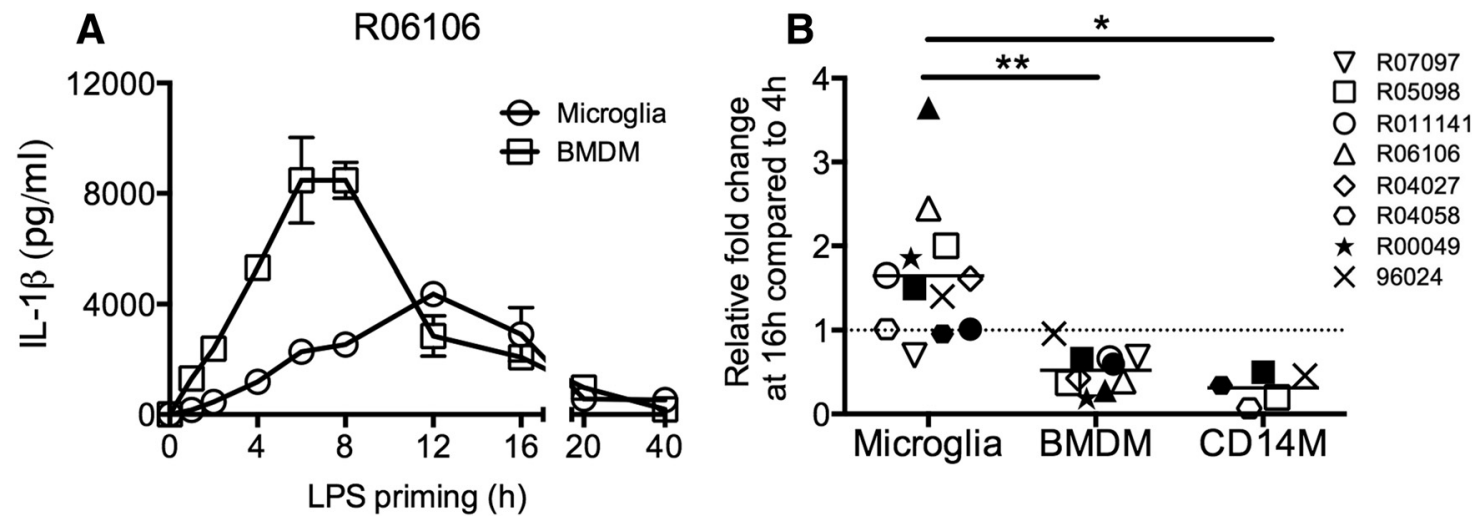

Figure 3. Kinetics of IL-1 $\beta$ secretion by LPS-primed microglia differ from that by LPS-primed hematopoietic macrophages. $A$, Silica-induced ( $500 \mu \mathrm{g} / \mathrm{ml}, 6 \mathrm{~h}$ ) IL-1 $\beta$ secretion in LPS-primed (100 $\mathrm{ng} / \mathrm{ml}$, indicated time points) microglia and BMDMs. Data of one representative donor of $\geq 3$ independent experiments are shown and are represented as mean \pm SD. $\boldsymbol{B}$, Analysis of the ratio of inflammasome-induced IL-1 $\beta$ secretion after $16 \mathrm{~h}$ to inflammasome-induced IL-1 $\beta$ secretion after $4 \mathrm{~h}$. Open symbols, Silica-induced IL- $1 \beta$ secretion; closed symbols, MSU-induced IL-1 $\beta$ secretion; ${ }^{*} p<0.05,{ }^{* *} p<0.01$; paired $t$ tests with Bonferroni's correction compared with microglia.
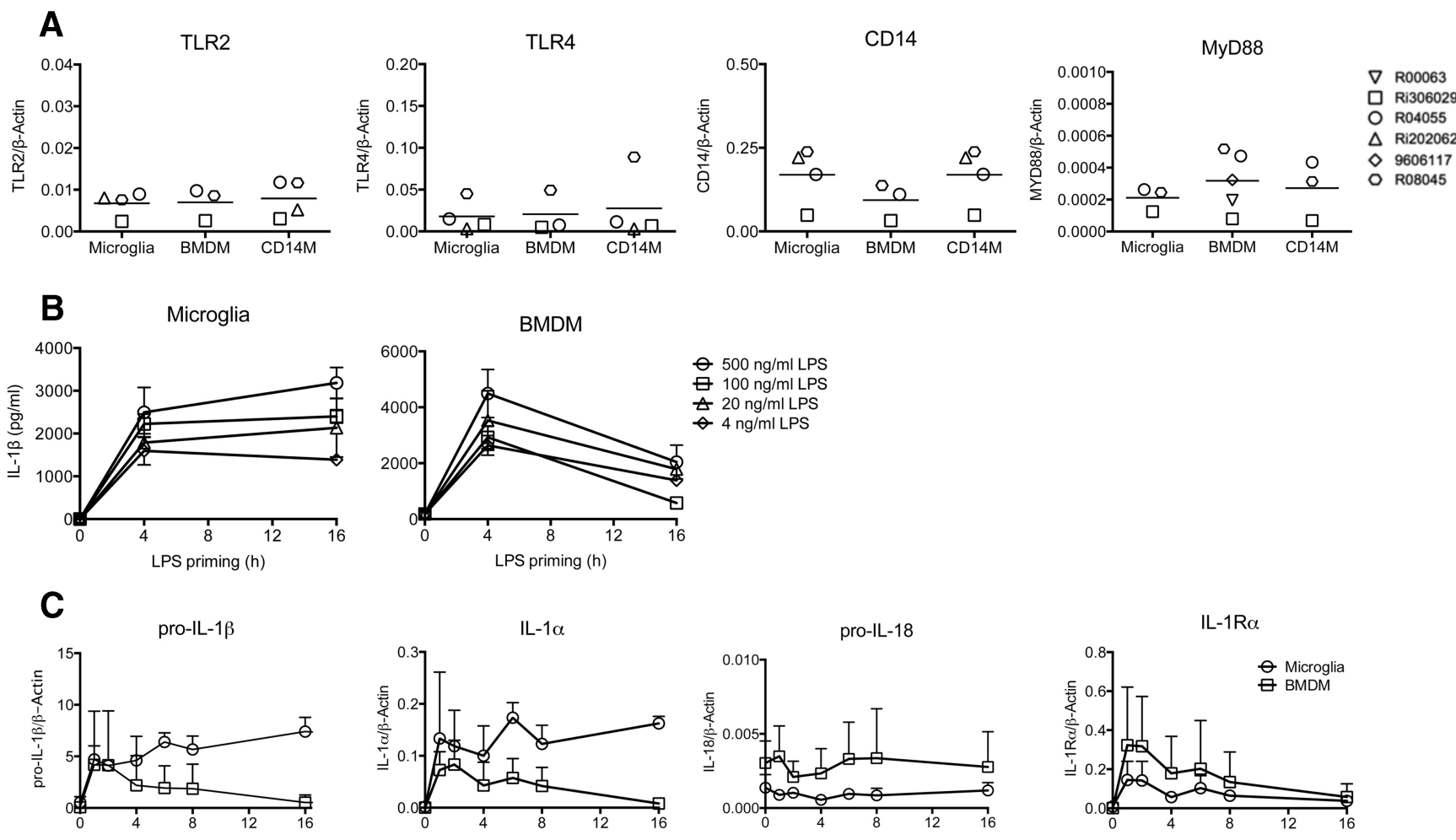

IL-8
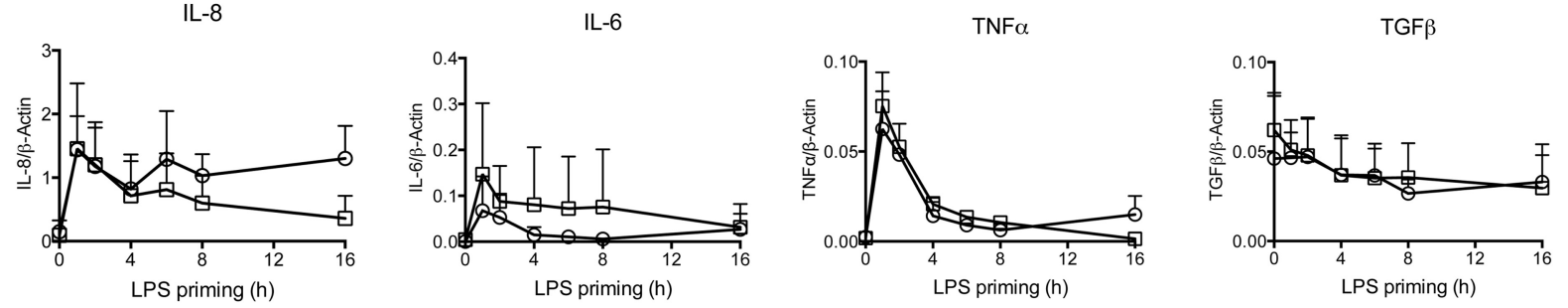

Figure 4. Negative regulation of pro-IL-1 $\beta$ transcription is impaired in microglia. $A$, Relative mRNA expression levels of TLR2, TLR4, CD14, and MyD88 in unprimed microglia, BMDMs, and CD14Ms. B, Silica-induced ( $500 \mu \mathrm{g} / \mathrm{ml}, 6 \mathrm{~h}$ ) IL-1 $\beta$ secretion of microglia and BMDMs primed with different concentrations of LPS (4-500 ng/ml, 4 or $16 \mathrm{~h})$. C, Relative pro-IL-1 $\beta$, IL- $1 \alpha$, pro-IL-18, IL-1R $\alpha$, IL-8, IL-6, TNF $\alpha$, and TGF $\beta$ (transforming growth factor $\beta$ ) mRNA expression levels in LPS-primed (100 ng/ml, indicated time points) microglia $(n=3)$ and BMDMs $(n=3)$. Data are represented as mean \pm SD.

Furthermore, we show that although microglia and hematopoietic macrophages respond to the same innate stimuli, microglial IL- $1 \beta$ secretion is optimal when longer priming periods are used and is more persistent when compared with hematopoietic macrophages. Together, our data demonstrate that the latter is due to a lack of negative regulation at the transcriptional level. This not only applies to LPS-induced pro-IL- $1 \beta$ mRNA expression levels, but also to IL-1 $\alpha$ and IL-8 mRNA expression levels. 

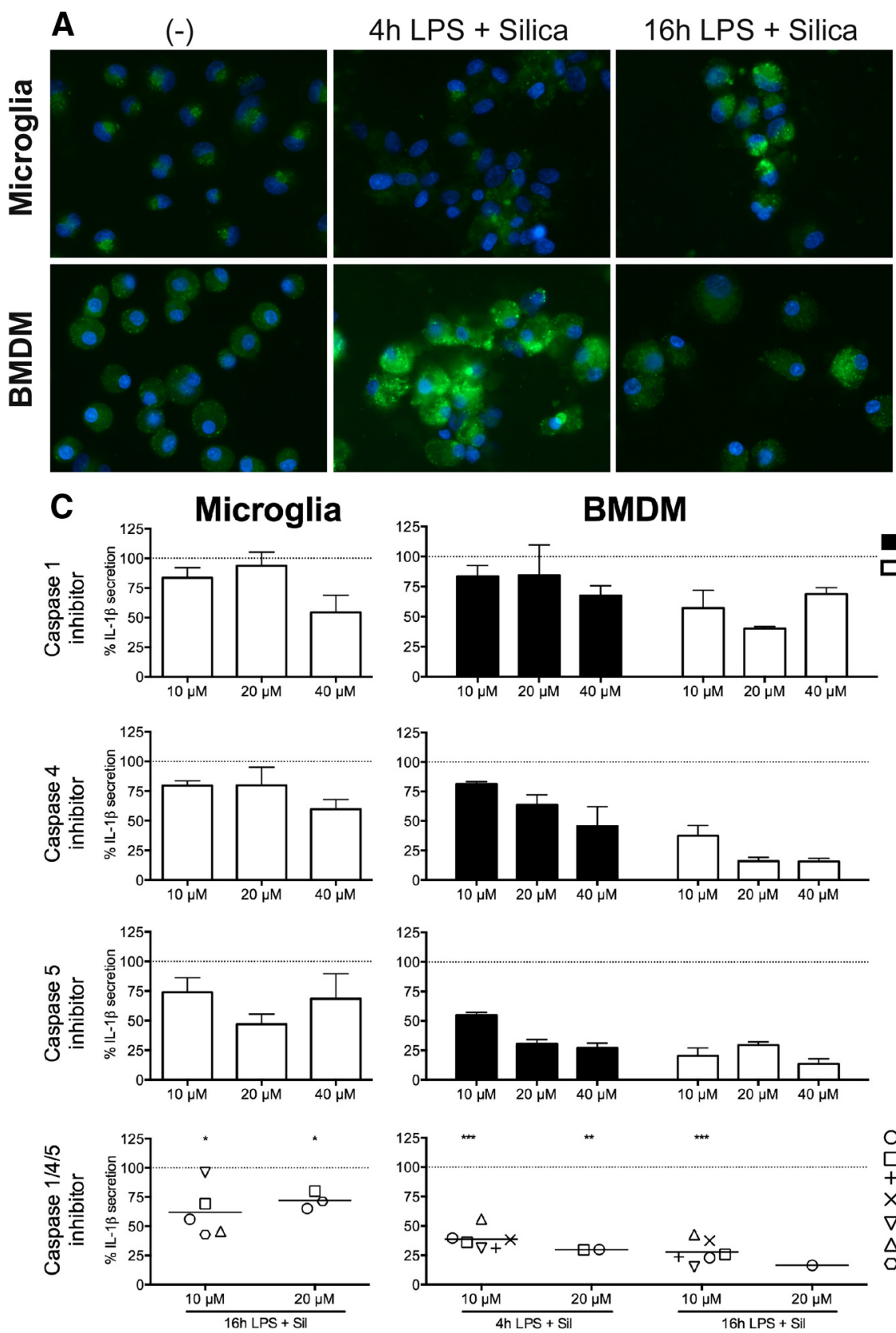

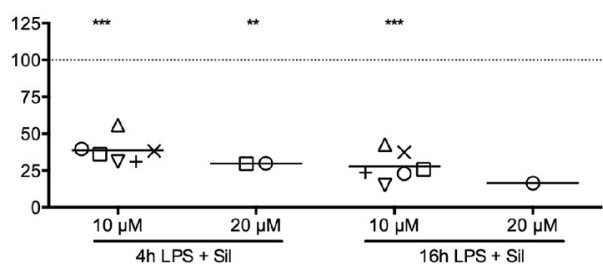

B

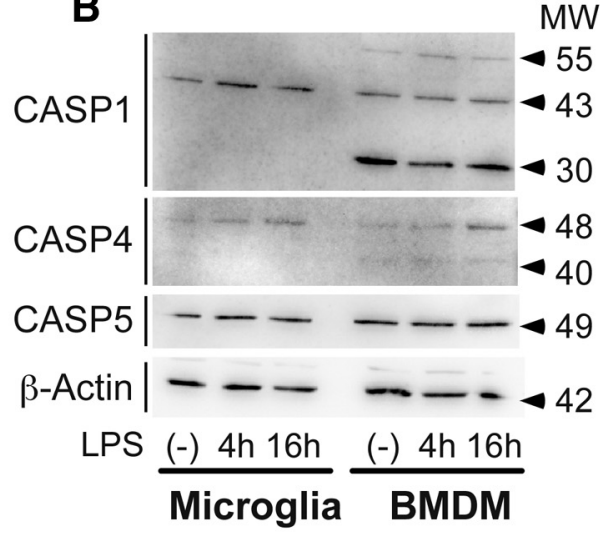

Figure 5. Silica-induced IL-1 $\beta$ secretion in microglia is only partially dependent of caspase 1, 4, and 5. A, Silica-induced ( $500 \mu \mathrm{g} / \mathrm{ml}, 30 \mathrm{~min}$ ) caspase 1 activation in LPS-primed ( $100 \mathrm{ng} / \mathrm{ml}$, indicated time points) microglia and BMDMs. Caspase 1 activation was assessed using fluorochrome inhibitor of caspase (FLICA) assays and results in a green fluorescent signal. Nuclei are counterstained with DAPI. Original magnifications $400 \times$. B. Western blot analysis of caspase 1, 4, and 5 expression in cell lysates of unprimed and LPS-primed (100 ng/ml, indicated time points) microglia and BMDMs. Arrows indicate molecular weight (MW) in kilodaltons. C, Analysis of silica-induced ( $500 \mu \mathrm{g} / \mathrm{ml}, 6 \mathrm{~h}$ ) IL-1 $\beta$ secretion by LPS-primed (100 ng/ml, indicated time points) microglia and BMDMs in the presence of $10-40 \mu \mathrm{m}$ specific caspase inhibitors or a combination of caspase 1, 4, and 5 inhibitors (10-20 $\mu \mathrm{m}$ each, all applied 15 min before silica activation). Data of one representative donor of $\geq 3$ independent experiments are shown for the separate caspase inhibitors, while data of multiple donors are shown for the combination of the caspase inhibitors. IL-1 $\beta$ secretion is represented relative to DMSO controls (dotted line, $100 \%$ ). DMSO or caspase inhibitors alone did not induce IL- $1 \beta$ secretion in unprimed or LPS-primed microglia and BMDMs. * $p<$ $0.05,{ }^{* *} p<0.01,{ }^{* * *} p<0.001$; paired $t$ tests with Bonferroni's correction compared with DMSO controls.

Transcription factor analysis (Champion ChiP Transcription Factor Search Portal, Qiagen; Lee et al., 1987; Cogswell et al., 1994; De Bosscher et al., 2003) revealed that the promoter regions of these cytokines share binding sites for the transcription factors $\mathrm{NF} \kappa \mathrm{B}, \mathrm{AP}-1, \mathrm{C} / \mathrm{EBP} \beta$ (CCAAT/enhancer binding protein $\beta$ ), and glucocorticoid receptor. Many proteins have been described that regulate the activation of these transcription factors, including regulatory proteins A20, SOCS1, TRIAD3A, SHP1, TOLLIP, IRAK-M (IL-1 receptor-associated kinase M), PELI1 (pellino E3 ubiquitin protein ligase 1), FLN29, and MAPK phosphatases
(Bajramovic, 2011). In microglia specifically, PELI1 can positively regulate $\mathrm{NF} \kappa \mathrm{B}$ signaling (Xiao et al., 2013). However, mRNA expression levels of PELI1 in microglia and hematopoietic macrophages were similar (data not shown), rendering it unlikely that this can directly explain the observed lack of negative regulation in microglia. Interestingly, NOD3 (also called NLRC3) has been found to negatively regulate NF $\kappa \mathrm{B}$ activation (Schneider et al., 2012). As our mRNA expression analysis revealed that microglia constitutively express much lower levels of NOD3-encoding transcripts than hematopoi- 
etic macrophages, NOD3 is an interesting candidate for future studies.

Various studies using primary microglia describe inflammasome-induced IL- $1 \beta$ secretion in response to protein aggregates and pathogens as caspase 1 dependent (Halle et al., 2008; Meissner et al., 2010; Terada et al., 2010; Hanamsagar et al., 2011; Hafner-Bratkovič et al., 2012; Jamilloux et al., 2013; Lee et al., 2013; Walsh et al., 2014). Our results confirm that microglial secretion of IL- $1 \beta$ is dependent on caspase 1 , but also demonstrate that this dependence is only partial. In addition, we demonstrate that although caspase 4 and 5 are involved in both microglia and hematopoietic macrophages, their relative contribution to inflammasome-induced IL- $1 \beta$ secretion appears to be less important in microglia. Our data on the simultaneous inhibition of caspase 1,4 , and 5 are in line with this notion. It has been reported that activation of caspase 4 and 5 can potentiate the activity of caspase 1 (Martinon et al., 2002; Sollberger et al., 2012) and this process might well be less efficient in microglia.

Overall our data show that microglia are less dependent than BMDMs on inflammatory caspases for the processing and secretion of IL- $1 \beta$ and suggest that they also employ other mechanisms. Alternative mechanisms that have been described for IL- $1 \beta$ processing and secretion include activation of a noncanonical caspase 8 inflammasome (Gringhuis et al., 2012; Antonopoulos et al., 2013) and inflammasome-independent mechanisms, such as matrix metalloproteinases (Schönbeck et al., 1998), cathepsins (Edye et al., 2013), and serine proteases (Joosten et al., 2009; Stehlik, 2009; Karmakar et al., 2012; Cassel et al., 2014). Preliminary results from our laboratory indicate that inhibition of caspase 8 does not affect silica-induced IL- $1 \beta$ secretion in either microglia or BMDMs (data not shown). The relative contribution of other pathways in microglial IL- $1 \beta$ secretion remains to be investigated.

This study, describing cell type-specific differences in the negative regulation of pro-IL- $1 \beta$ expression and in the enzymatic processing of pro-IL- $1 \beta$, concurs with recently described fundamental differences in inflammasome-mediated activation of monocytes and macrophages (Netea et al., 2009). Whether such differences are cell inherent (Ginhoux et al., 2010) or induced by prolonged exposure to the neuronal microenvironment is currently unknown. It also remains to be demonstrated how the differences described here translate to tissue-specific responses to chronic or acute cellular stress in vivo. Currently, inhibition of caspase 1 activation is considered a therapeutic strategy to reduce inflammation in neuroinflammatory diseases (Rabuffetti et al., 2000). Our results suggest that this strategy might only be partially effective on microglia. To develop therapeutic strategies that target IL- $1 \beta$ processing and secretion in microglia specifically, it is important to delineate the additional mechanisms used by microglia for the secretion of IL- $1 \beta$.

\section{References}

Abulafia DP, de Rivero Vaccari JP, Lozano JD, Lotocki G, Keane RW, Dietrich WD (2009) Inhibition of the inflammasome complex reduces the inflammatory response after thromboembolic stroke in mice. J Cereb Blood Flow Metab 29:534-544. CrossRef Medline

Antonopoulos C, El Sanadi C, Kaiser WJ, Mocarski ES, Dubyak GR (2013) Proapoptotic chemotherapeutic drugs induce noncanonical processing and release of IL-1beta via caspase-8 in dendritic cells. J Immunol 191: 4789-4803. CrossRef Medline

Bajramovic JJ (2011) Regulation of innate immune responses in the central nervous system. CNS Neurol Disord Drug Targets 10:4-24. CrossRef Medline
Burguillos MA, Deierborg T, Kavanagh E, Persson A, Hajji N, GarciaQuintanilla A, Cano J, Brundin P, Englund E, Venero JL, Joseph B (2011) Caspase signalling controls microglia activation and neurotoxicity. Nature 472:319-324. CrossRef Medline

Butovsky O, Jedrychowski MP, Moore CS, Cialic R, Lanser AJ, Gabriely G, Koeglsperger T, Dake B, Wu PM, Doykan CE, Fanek Z, Liu L, Chen Z, Rothstein JD, Ransohoff RM, Gygi SP, Antel JP, Weiner HL (2014) Identification of a unique TGF- $\beta$-dependent molecular and functional signature in microglia. Nat Neurosci 17:131-143. CrossRef Medline

Cassel SL, Janczy JR, Bing X, Wilson SP, Olivier AK, Otero JE, Iwakura Y, Shayakhmetov DM, Bassuk AG, Abu-Amer Y, Brogden KA, Burns TL, Sutterwala FS, Ferguson PJ (2014) Inflammasome-independent IL1beta mediates autoinflammatory disease in Pstpip2-deficient mice. Proc Natl Acad Sci U S A 111:1072-1077. CrossRef Medline

Chang J, Yang L, Kouadir M, Peng Y, Zhang S, Shi F, Zhou X, Yin X, Zhao D (2012) Antibody-mediated inhibition of integrin alpha5betal blocks neurotoxic prion peptide PrP106-126-induced activation of BV2 microglia. J Mol Neurosci 48:248-252. CrossRef Medline

Chiu IM, Morimoto ET, Goodarzi H, Liao JT, O'Keeffe S, Phatnani HP, Muratet M, Carroll MC, Levy S, Tavazoie S, Myers RM, Maniatis T (2013) A neurodegeneration-specific gene-expression signature of acutely isolated microglia from an amyotrophic lateral sclerosis mouse model. Cell Rep 4:385-401. CrossRef Medline

Cogswell JP, Godlevski MM, Wisely GB, Clay WC, Leesnitzer LM, Ways JP, Gray JG (1994) NF-kappa B regulates IL-1 beta transcription through a consensus NF-kappa B binding site and a nonconsensus CRE-like site. J Immun 153:712-723. Medline

De Bosscher K, Vanden Berghe W, Haegeman G (2003) The interplay between the glucocorticoid receptor and nuclear factor-kappaB or activator protein-1: molecular mechanisms for gene repression. Endocr Rev 24: 488-522. CrossRef Medline

Edye ME, Lopez-Castejon G, Allan SM, Brough D (2013) Acidosis drives damage-associated molecular pattern (DAMP)-induced interleukin-1 secretion via a caspase-1-independent pathway. J Biol Chem 288:3048530494. CrossRef Medline

Euser SM, Hofman A, Westendorp RG, Breteler MM (2009) Serum uric acid and cognitive function and dementia. Brain 132:377-382. CrossRef Medline

Furr SR, Chauhan VS, Sterka D Jr, Grdzelishvili V, Marriott I (2008) Characterization of retinoic acid-inducible gene-I expression in primary murine glia following exposure to vesicular stomatitis virus. J Neurovirol 14:503-513. CrossRef Medline

Ginhoux F, Greter M, Leboeuf M, Nandi S, See P, Gokhan S, Mehler MF, Conway SJ, Ng LG, Stanley ER, Samokhvalov IM, Merad M (2010) Fate mapping analysis reveals that adult microglia derive from primitive macrophages. Science 330:841-845. CrossRef Medline

Greenhalgh AD, David S (2014) Differences in the phagocytic response of microglia and peripheral macrophages after spinal cord injury and its effects on cell death. J Neurosci 34:6316-6322. CrossRef Medline

Gringhuis SI, Kaptein TM, Wevers BA, Theelen B, van der Vlist M, Boekhout T, Geijtenbeek TB (2012) Dectin-1 is an extracellular pathogen sensor for the induction and processing of IL-1beta via a noncanonical caspase- 8 inflammasome. Nat Immunol 13:246-254. CrossRef Medline

Hafner-Bratkovič I, Benčina M, Fitzgerald KA, Golenbock D, Jerala R (2012) NLRP3 inflammasome activation in macrophage cell lines by prion protein fibrils as the source of IL-1beta and neuronal toxicity. Cell Mol Life Sci 69:4215-4228. CrossRef Medline

Halle A, Hornung V, Petzold GC, Stewart CR, Monks BG, Reinheckel T, Fitzgerald KA, Latz E, Moore KJ, Golenbock DT (2008) The NALP3 inflammasome is involved in the innate immune response to amyloidbeta. Nat Immunol 9:857-865. CrossRef Medline

Hanamsagar R, Torres V, Kielian T (2011) Inflammasome activation and IL-1beta/IL-18 processing are influenced by distinct pathways in microglia. J Neurochem 119:736-748. CrossRef Medline

Heneka MT, Kummer MP, Stutz A, Delekate A, Schwartz S, Vieira-Saecker A, Griep A, Axt D, Remus A, Tzeng TC, Gelpi E, Halle A, Korte M, Latz E, Golenbock DT (2013) NLRP3 is activated in Alzheimer's disease and contributes to pathology in APP/PS1 mice. Nature 493:674-678. CrossRef Medline

Hickman SE, Kingery ND, Ohsumi TK, Borowsky ML, Wang LC, Means TK, El Khoury J (2013) The microglial sensome revealed by direct RNA sequencing. Nat Neurosci 16:1896-1905. CrossRef Medline

Jamilloux Y, Pierini R, Querenet M, Juruj C, Fauchais AL, Jauberteau MO, 
Jarraud S, Lina G, Etienne J, Roy CR, Henry T, Davoust N, Ader F (2013) Inflammasome activation restricts Legionella pneumophila replication in primary microglial cells through flagellin detection. Glia 61:539-549. CrossRef Medline

Joosten LA, Netea MG, Fantuzzi G, Koenders MI, Helsen MM, Sparrer H, Pham CT, van der Meer JW, Dinarello CA, van den Berg WB (2009) Inflammatory arthritis in caspase 1 gene-deficient mice: contribution of proteinase 3 to caspase 1-independent production of bioactive interleukin-1beta. Arthritis Rheum 60:3651-3662. CrossRef Medline

Karmakar M, Sun Y, Hise AG, Rietsch A, Pearlman E (2012) Cutting edge: IL-1beta processing during Pseudomonas aeruginosa infection is mediated by neutrophil serine proteases and is independent of NLRC4 and caspase-1. J Immunol 189:4231-4235. CrossRef Medline

Kaushik DK, Gupta M, Kumawat KL, Basu A (2012) NLRP3 inflammasome: key mediator of neuroinflammation in murine Japanese encephalitis. PloS One 7:e32270. CrossRef Medline

Khare S, Dorfleutner A, Bryan NB, Yun C, Radian AD, de Almeida L, Rojanasakul Y, Stehlik C (2012) An NLRP7-containing inflammasome mediates recognition of microbial lipopeptides in human macrophages. Immunity 36:464-476. CrossRef Medline

Latz E (2010) The inflammasomes: mechanisms of activation and function. Curr Opin Immunol 22:28-33. CrossRef Medline

Lee HM, Kang J, Lee SJ, Jo EK (2013) Microglial activation of the NLRP3 inflammasome by the priming signals derived from macrophages infected with mycobacteria. Glia 61:441-452. CrossRef Medline

Lee W, Mitchell P, Tjian R (1987) Purified transcription factor AP-1 interacts with TPA-inducible enhancer elements. Cell 49:741-752. CrossRef Medline

Maetzler W, Stapf AK, Schulte C, Hauser AK, Lerche S, Wurster I, Schleicher E, Melms A, Berg D (2011) Serum and cerebrospinal fluid uric acid levels in lewy body disorders: associations with disease occurrence and amyloid-beta pathway. J Alzheimers Dis 27:119-126. CrossRef Medline

Martinon F, Tschopp J (2004) Inflammatory caspases: linking an intracellular innate immune system to autoinflammatory diseases. Cell 117:561574. CrossRef Medline

Martinon F, Burns K, Tschopp J (2002) The inflammasome: a molecular platform triggering activation of inflammatory caspases and processing of proIL-beta. Mol Cell 10:417-426. CrossRef Medline

Martinon F, Pétrilli V, Mayor A, Tardivel A, Tschopp J (2006) Goutassociated uric acid crystals activate the NALP3 inflammasome. Nature 440:237-241. CrossRef Medline

Martinon F, Mayor A, Tschopp J (2009) The inflammasomes: guardians of the body. Annu Rev Immunol 27:229-265. CrossRef Medline

Martins I, Wang Y, Michaud M, Ma Y, Sukkurwala AQ, Shen S, Kepp O, Métivier D, Galluzzi L, Perfettini JL, Zitvogel L, Kroemer G (2014) Molecular mechanisms of ATP secretion during immunogenic cell death. Cell Death Differ 21:79-91. CrossRef Medline

McFarland NR, Burdett T, Desjardins CA, Frosch MP, Schwarzschild MA (2013) Postmortem brain levels of urate and precursors in Parkinson's disease and related disorders. Neurodegener Dis 12:189-198. CrossRef Medline

Meissner F, Molawi K, Zychlinsky A (2010) Mutant superoxide dismutase 1-induced IL-1beta accelerates ALS pathogenesis. Proc Natl Acad Sci U S A 107:13046-13050. CrossRef Medline

Netea MG, Nold-Petry CA, Nold MF, Joosten LA, Opitz B, van der Meer JH, van de Veerdonk FL, Ferwerda G, Heinhuis B, Devesa I, Funk CJ, Mason RJ, Kullberg BJ, Rubartelli A, van der Meer JW, Dinarello CA (2009) Differential requirement for the activation of the inflammasome for processing and release of IL-1beta in monocytes and macrophages. Blood 113:2324-2335. CrossRef Medline

Olson JK, Miller SD (2004) Microglia initiate central nervous system innate and adaptive immune responses through multiple TLRs. J Immunol 173: 3916-3924. CrossRef Medline

Pfaffl MW (2001) A new mathematical model for relative quantification in real-time RT-PCR. Nucleic Acids Res 29:e45. CrossRef Medline

Rabuffetti M, Sciorati C, Tarozzo G, Clementi E, Manfredi AA, Beltramo M (2000) Inhibition of caspase-1-like activity by Ac-Tyr-Val-Ala-Aspchloromethyl ketone induces long-lasting neuroprotection in cerebral ischemia through apoptosis reduction and decrease of proinflammatory cytokines. J Neurosci 20:4398-4404. Medline
Raivich G, Banati R (2004) Brain microglia and blood-derived macrophages: molecular profiles and functional roles in multiple sclerosis and animal models of autoimmune demyelinating disease. Brain Res Brain Res Rev 46:261-281. CrossRef Medline

Rock KL, Kono H (2008) The inflammatory response to cell death. Annu Rev Pathol 3:99-126. CrossRef Medline

Salminen A, Ojala J, Suuronen T, Kaarniranta K, Kauppinen A (2008) Amyloid-beta oligomers set fire to inflammasomes and induce Alzheimer's pathology. J Cell Mol Med 12:2255-2262. CrossRef Medline

Schneider M, Zimmermann AG, Roberts RA, Zhang L, Swanson KV, Wen H, Davis BK, Allen IC, Holl EK, Ye Z, Rahman AH, Conti BJ, Eitas TK, Koller BH, Ting JP (2012) The innate immune sensor NLRC3 attenuates Toll-like receptor signaling via modification of the signaling adaptor TRAF6 and transcription factor NF-kappaB. Nat Immunol 13:823-831. CrossRef Medline

Schönbeck U, Mach F, Libby P (1998) Generation of biologically active IL-1 beta by matrix metalloproteinases: a novel caspase-1-independent pathway of IL-1 beta processing. J Immunol 161:3340-3346. Medline

Shah VB, Huang Y, Keshwara R, Ozment-Skelton T, Williams DL, Keshvara L (2008) Beta-glucan activates microglia without inducing cytokine production in Dectin-1-dependent manner. J Immunol 180:2777-2785. CrossRef Medline

Shi F, Yang L, Kouadir M, Yang Y, Wang J, Zhou X, Yin X, Zhao D (2012) The NALP3 inflammasome is involved in neurotoxic prion peptide-induced microglial activation. J Neuroinflammation 9:73. CrossRef Medline

Shi F, Yang L, Kouadir M, Yang Y, Ding T, Wang J, Zhou X, Yin X, Zhao D (2013) Prion protein participates in the regulation of classical and alternative activation of BV2 microglia. J Neurochem 124:168-174. CrossRef Medline

Shi Y, Evans JE, Rock KL (2003) Molecular identification of a danger signal that alerts the immune system to dying cells. Nature 425:516-521. CrossRef Medline

Sollberger G, Strittmatter GE, Kistowska M, French LE, Beer HD (2012) Caspase-4 is required for activation of inflammasomes. J Immunol 188: 1992-2000. CrossRef Medline

Stehlik C (2009) Multiple interleukin-1beta-converting enzymes contribute to inflammatory arthritis. Arthritis Rheum 60:3524-3530. CrossRef Medline

Terada K, Yamada J, Hayashi Y, Wu Z, Uchiyama Y, Peters C, Nakanishi H (2010) Involvement of cathepsin B in the processing and secretion of interleukin-1beta in chromogranin A-stimulated microglia. Glia 58:114124. CrossRef Medline

Ting JP, Duncan JA, Lei Y (2010) How the noninflammasome NLRs function in the innate immune system. Science 327:286-290. CrossRef Medline

van der Putten C, Zuiderwiik-Sick EA, van Straalen L, de Geus ED, Boven LA, Kondova I, Ijzerman AP, Bajramovic JJ (2009) Differential expression of adenosine $\mathrm{A} 3$ receptors controls adenosine $\mathrm{A} 2 \mathrm{~A}$ receptor-mediated inhibition of TLR responses in microglia. J Immunol 182:7603-7612. CrossRef Medline

Walsh JG, Reinke SN, Mamik MK, McKenzie BA, Maingat F, Branton WG, Broadhurst DI, Power C (2014) Rapid inflammasome activation in microglia contributes to brain disease in HIV/AIDS. Retrovirology 11:35. CrossRef Medline

Wu Z, Sun L, Hashioka S, Yu S, Schwab C, Okada R, Hayashi Y, McGeer PL, Nakanishi H (2013) Differential pathways for interleukin-1beta production activated by chromogranin A and amyloid beta in microglia. Neurobiol Aging 34:2715-2725. CrossRef Medline

Xiao Y, Jin J, Chang M, Chang JH, Hu H, Zhou X, Brittain GC, Stansberg C, Torkildsen Ø, Wang X, Brink R, Cheng X, Sun SC (2013) Pelil promotes microglia-mediated CNS inflammation by regulating Traf3 degradation. Nat Med 19:595-602. CrossRef Medline

Zhou R, Yazdi AS, Menu P, Tschopp J (2011) A role for mitochondria in NLRP3 inflammasome activation. Nature 469:221-225. CrossRef Medline

Zuiderwijk-Sick EA, van der Putten C, Bsibsi M, Deuzing IP, de Boer W, Persoon-Deen C, Kondova I, Boven LA, van Noort JM, 't Hart BA, Amor S, Bajramovic JJ (2007) Differentiation of primary adult microglia alters their response to TLR8-mediated activation but not their capacity as APC. Glia 55:1589-1600. CrossRef Medline 